\begin{tabular}{ccc}
\hline & International Journal of Engineering \& Technology, $7(3.30)(2018) 571-574$ \\
SPC & International Journal of Engineering \& Technology \\
\hline
\end{tabular}

\title{
The Role of Leaders in Stimulating Innovative Work Behavior and its Impacts towards Job Performance (Case Study: PT. XYZ)
}

\author{
Jefta Harlianto ${ }^{* 1}$, Rudi ${ }^{2}$, Dessy Afandy ${ }^{3}$ \\ ${ }^{1}$ Management, BINUS Business School Undergraduate Program, BINUS University \\ * Corresponding author E-mail: jefta@binus.edu 1
}

\begin{abstract}
Nowadays, companies are operating in a changing world and competitive market. PT. XYZ realizes that innovation is the key for company to be able to remain competitive. Creating an innovative environment within the company requires both leaders' role and employees' involvement. Leaders should have a role to empower employees to be innovative in the workplace. Employees with innovative work behavior will drive their individual job performance, thus improving organization performance. The aim of this study is to examine the role of PT. XYZ's leaders in stimulating innovative work behavior of their employees. This study applied seven leader behaviors of J. P. J. De Jong \& Hartog (2007) that have direct impact in stimulating innovative work behavior of employee. A paper based questionnaire was used to collect the data about employee perception about their leaders' roles, innovative work behavior and job performance. Based on Slovin formula sampling technique, there were 299 respondents from 815 employees' population taken for this study. Partial Least Square Method is used to find the significant level between multiple dependent variables and multiple independent variables. The result of this study found that Consulting (T-statistics $=2.815$, p-value $=0.003)$, Providing Resources $(T-$ statistics $=2.510, p$-value $=0.006)$ and Task Assignment (T-statistics $=3.250$, p-value $=0.001$ ) have significant effect on employee innovative work behavior. Although Delegating, Supporting for innovation, Recognizing, and Monitoring from the leaders have no significant effect on innovative work behavior, the organization might provide effect to these four behaviors. The result also shows that employee innovative work behaviors have significant effect on Job Performance (T-statistics=2.503, p-value=0.006).
\end{abstract}

Keywords: Leaders' roles, innovative work behavior, job performance.

\section{Introduction}

Fast growing business competition requires company have to quickly adapt, continuously innovating to keep staying in the long run competition. Porter in 1990 pointed out that competition started by the late of twentieth century is about leadership competition, how the leader can lead the organization to perform continuous innovation. Many scientists believe that employees become one of the important aspects for companies to become more innovative (Dorner, 2012; Janssen, 2000; J. P. J. De Jong \& Hartog, 2007), and one way that companies can do is by capitalizing on their employees through the employees ability to generate ideas. In this context, employee can help the company to improve business performance (J. P. J. De Jong \& Hartog, 2007). Thus leaders have an important role to motivate their employee in terms of enhancing work innovative behavior (Akram, Ali, \& Mughal, 2012; J. De Jong \& Hartog, 2003). Basadur (2004, p. 103) in J. P. J. De Jong $\&$ Hartog (2007) characterized that the most effective leaders in the future as in the following quote : ... will help individuals (.. .) to coordinate and integrate their differing styles through a process of applied creativity that includes continuously discovering and defining new problems, solving those problems and implementing the new solutions.

Due to tight competition, PT. XYZ has to create diverse breakthrough in order to stay ahead of the competition. PT. XYZ has a set of organization values, and one of the values is innovation. Leaders have implemented many programs to encourage employee innovative behavior but there were fluctuations in employee performance appraisal results in the last three years. Therefore, the objective of this study is to examine the role of PT. XYZ's leaders in stimulating innovative work behavior of their employees and furthermore to find out whether innovative work behavior is able to improve job performance.

This study applied seven leader behaviors of J. P. J. De Jong \& Hartog (2007) that have direct impact in stimulating innovative work behavior of employee. The scope of this study will be focused on leader as one important aspect which allegedly influence work innovative behavior, even though innovative behavior can be influenced by other aspects (De Jong and Hartog, 2003).

\section{Literature Review}

\subsection{Innovative Work Behavior}

West and Farr in Dorner (2012) defined innovative work behavior (IWB) as "the intentional generation, promotion and realization of new ideas within a work role, workgroup or organization in order to benefit role performance, the group or the organization". Patterson (2009) views innovation and creativity as overlapping constructs and feels the need to distinguish between the two concepts. But both are believed to be related to new things. Creativity is 
exclusively concerned with generating new and entirely original ideas. Innovation is a broader concept because it also includes applying new ideas to produce something new and useful (in the context of groups, organizations or communities). Innovation is often referred to as a process, because applying new ideas needs to involve others (whereas creativity can be achieved separately). Employee innovation goes beyond individual creativity because it also concerns the extent to which employees apply and sustain innovation. De Jong \& Hartog (2007) and Xerri \& Brunetto (2011) stated that individual's ability to innovate contribute to the innovation in the organization level and have crucial impact to the performance and survival of the organizations. Janssen in 2000 was first to divide IWB into stages which were idea exploration, idea generation, idea championing and idea implementation that enhanced by De Jong into four stages that have different activities. Although IWB is theoretically treated as multi-dimensional but IWB can theoretically be well understood if one considers the IWB dimension as a different stage, that is why most studies use a one-dimensional measure of IWB because IWB processes in practice seems overlapping because in some condition, individuals are expected to engage simultaneously (De Jong \& Den Hartog, 2010). This is the reason why the concept of IWB is considered one dimension in this study (T. Oukes, 2010). De Jong (2007) and Dorner (2012) examined ten items covering individual innovative work behavior which include the generation of new idea, the behavior involved in implementing these ideas. Even if different elements are included, they are treated as one-dimensional in measurement. De Jong and Den Hartog (2003) explored seven behaviors of innovation-enhancing leadership that trigger innovative behavior of employee which are 1) consulting, this behavior encourage employee to participate in decision-making; 2) delegating, this behavior more focus on giving automony to do their job; 3) support innovation, how leaders showing their enthusiasm to the employee idea and creativity; 4) recognizing, leaders should give credit for their employee to make them feel that his or her effort are recognized; 5) providing resources, supporting the employee to implement their idea by investing time and money; 6) monitoring, monitoring may have boh positive and negative impact to the innnovation behavior especially if this related to efficiency and effectiveness; 7) task assignment, this leader behaviour aimed at clarifying work roles, and responsibilities that fits with the passion and abilities of their employee.

\subsection{Job Performance}

Drs. J. Tanzil \& Associated as Registered Public Accountant Tax and Management Consultants explained KPI as a performance measurement tool that consists of some of key indicators that are measurable and are able to provide information on the extent to which a company's strategic goals or the objective of a position have been successfully achieved. Researchers were trying to assess job performance using employee perspective (Pugno \& Depedri, 2010; Alfes, Truss, Soane, Rees, \& Gatenby, 2013), while other using supervisor perspective (Dorner, 2012) and the others are trying to captures job performance from both sides (Judge, Thoresen, Bono, \& Patton, 2001; De Jong, 2007). PT. $\mathrm{XYZ}$ is using Key Performance Indicator (KPI) to evaluate individual job performance over the years. Individual KPI is designed unique and is the reflection of a job description for every position. The progress of items in the KPI is monitored monthly and quarterly to let employee and supervisor know which items have not been achieved. By doing so, they are able to identify which area that still needs improvement and evaluate their strategy in order to achieve that target. In the assessment process, employees have time to proof their achievement by providing supporting evidence. The result of KPI score will be verified by supervisor. In this research, scholar will use KPI as observed variable that can appropriately represent employee job performance.

\section{Methodology}

The essence of this research is synthesized from several previous studies which are (1) Jong, J. De, \& Hartog, D. Den. (2003). Leadership as a determinant of innovative behaviour: A conceptual framework. (2) Jeroen P.J. de Jong (2007) "Individual Innovation: The Connection Between Leadership and Employees' Innovative Work Behavior"; (3) Oukes, T. (2010). Innovative work behavior. (4) Nadin Dorner (2012) "Innovative Work Behavior: The Roles of Employee Expectations and Effects on Job Performance",

This research is trying to answer this following research questions:

1. Does each of innovation-enhancing leader behavior have impact to innovative work behavior?

2. Does employee innovative work behavior have impact on employee job performance?

To answer the research questions, scholar compiled the research framework shown in Figure 1.

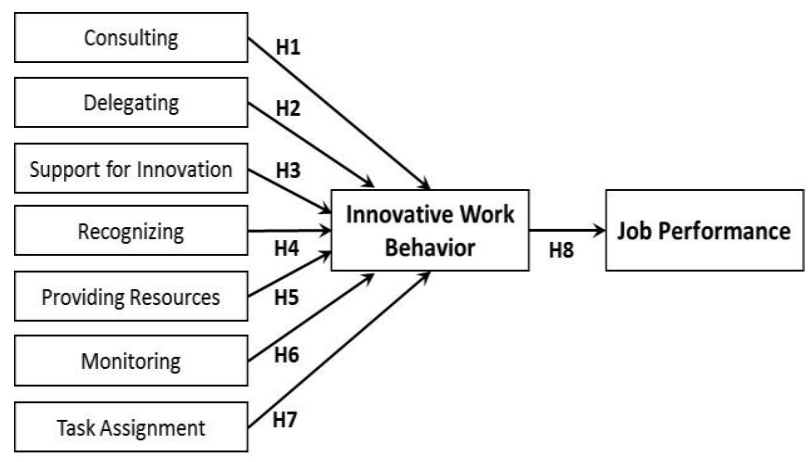

Fig. 1: Research Framework

According to the problem identifications and according to the model presented in Figure 1, there are several hypotheses can be proposed:

Hypothesis 1 : Consulting has effect on innovative work behavior Hypothesis 2 : Delegating has effect on innovative work behavior Hypothesis 3 : Support for innovation has effect on innovative work behavior

Hypothesis 4 : Recognizing has effect on innovative work behavior

Hypothesis 5 : Providing resources has effect on innovative work behavior

Hypothesis 6 : Monitoring has effect on innovative work behavior Hypothesis 7 : Task assignment has effect on innovative work behavior

Hypothesis 8 : Innovative work behavior has effect on job performance

Table 1: Operational Variables

\begin{tabular}{|c|c|c|c|}
\hline Variable & Description & Items & Source \\
\hline \multirow{4}{*}{ Consulting } & \multirow{4}{*}{$\begin{array}{l}\text { Leader that en- } \\
\text { courage their em- } \\
\text { ployee/subordinate } \\
\text { to participate in } \\
\text { decision-making }\end{array}$} & $\begin{array}{l}\text { - Asks for } \\
\text { my opinion }\end{array}$ & \multirow{4}{*}{$\begin{array}{l}\text { Jeroen } \\
\text { P.J. de } \\
\text { Jong } \\
(2007)\end{array}$} \\
\hline & & $\begin{array}{l}\text { - Consults } \\
\text { me about important } \\
\text { changes }\end{array}$ & \\
\hline & & $\begin{array}{l}-\overline{\text { Let's me }} \\
\text { influence decisions } \\
\text { about long term plans } \\
\text { and directions }\end{array}$ & \\
\hline & & $\begin{array}{l}\text { - Asks me to } \\
\text { suggest how to carry } \\
\text { out assignments }\end{array}$ & \\
\hline \multirow{3}{*}{ Delegating } & \multirow{3}{*}{$\begin{array}{l}\text { Leader that more } \\
\text { focus on giving } \\
\text { autonomy to do } \\
\text { their job }\end{array}$} & $\begin{array}{l}\text { Allows me } \\
\text { to decide myself how I } \\
\text { do my work }\end{array}$ & \multirow{3}{*}{$\begin{array}{l}\text { Jeroen } \\
\text { P.J. de } \\
\text { Jong } \\
(2007)\end{array}$} \\
\hline & & $\begin{array}{l}\text { - Gives me } \\
\text { considerable inde- } \\
\text { pendence and freedom }\end{array}$ & \\
\hline & & Allows me & \\
\hline
\end{tabular}




\begin{tabular}{|c|c|c|c|}
\hline Variable & Description & Items & Source \\
\hline & & $\begin{array}{l}\text { to determine my own } \\
\text { time planning }\end{array}$ & \\
\hline \multirow{4}{*}{$\begin{array}{l}\text { Support } \\
\text { for innova- } \\
\text { tion }\end{array}$} & \multirow{4}{*}{$\begin{array}{l}\text { Leaders are show- } \\
\text { ing their enthusias- } \\
\text { tic to the employee } \\
\text { idea and creativity }\end{array}$} & $\begin{array}{l}\text { - Shows } \\
\text { sincere interest when- } \\
\text { ever I come up with an } \\
\text { idea }\end{array}$ & \multirow{4}{*}{$\begin{array}{l}\text { Jeroen } \\
\text { P.J. de } \\
\text { Jong } \\
(2007)\end{array}$} \\
\hline & & $\begin{array}{l}\text { Reacts } \\
\text { enthusiastically to my } \\
\text { creative thoughts }\end{array}$ & \\
\hline & & $\begin{array}{l}\text { - Supports } \\
\text { me when I want to } \\
\text { improve things }\end{array}$ & \\
\hline & & $\begin{array}{l}\text { Is someone } \\
\text { when I initiate some- } \\
\text { thing unsuccessful }\end{array}$ & \\
\hline \multirow{4}{*}{$\begin{array}{l}\text { Recogniz- } \\
\text { ing }\end{array}$} & \multirow{4}{*}{$\begin{array}{l}\text { Leaders give credit } \\
\text { for their employee } \\
\text { to make them feel } \\
\text { that his or her } \\
\text { effort are recog- } \\
\text { nized }\end{array}$} & $\begin{array}{l}\text { - Publicly } \\
\text { recognizes me when I } \\
\text { am innovative }\end{array}$ & \multirow{4}{*}{$\begin{array}{l}\text { Jeroen } \\
\text { P.J. de } \\
\text { Jong } \\
(2007)\end{array}$} \\
\hline & & $\begin{array}{ll}- & \text { Praises my } \\
\text { innovative efforts } & \\
\end{array}$ & \\
\hline & & $\begin{array}{l}- \\
\text { Recognizes } \\
\text { my contribution to } \\
\text { innovation }\end{array}$ & \\
\hline & & $\begin{array}{l}\text { - Gives me } \\
\text { credit for innovative } \\
\text { ideas }\end{array}$ & \\
\hline \multirow{3}{*}{$\begin{array}{l}\text { Providing } \\
\text { resources }\end{array}$} & \multirow{3}{*}{$\begin{array}{l}\text { Leaders that sup- } \\
\text { porting their em- } \\
\text { ployee/ subordinate } \\
\text { to explore, develop } \\
\text { and implement the } \\
\text { idea by investing } \\
\text { time and money }\end{array}$} & $\begin{array}{l}\text { - Provides } \\
\text { me with time to work } \\
\text { out ideas }\end{array}$ & \multirow{3}{*}{$\begin{array}{l}\text { Jeroen } \\
\text { P.J. de } \\
\text { Jong } \\
(2007)\end{array}$} \\
\hline & & $\begin{array}{l}- \\
\text { me with the means } \\
\text { necessary for innova- } \\
\text { tion }\end{array}$ & \\
\hline & & $\begin{array}{l}\text { - Is willing to } \\
\text { invest time and money } \\
\text { in innovative efforts }\end{array}$ & \\
\hline \multirow{3}{*}{ Monitoring } & \multirow{3}{*}{$\begin{array}{l}\text { Leaders keep on } \\
\text { tracking the pro- } \\
\text { gress of the inno- } \\
\text { vative process }\end{array}$} & $\begin{array}{l}\text { Gathering } \\
\text { information about } \\
\text { work activities and } \\
\text { external conditions } \\
\text { affecting the work }\end{array}$ & \multirow{3}{*}{$\begin{array}{l}\text { Jeroen } \\
\text { P.J. de } \\
\text { Jong } \\
(2007)\end{array}$} \\
\hline & & $\begin{array}{l}\text { Checking } \\
\text { on the progress and } \\
\text { quality of the work }\end{array}$ & \\
\hline & & $\begin{array}{l}\text { Evaluating } \\
\text { the performance of } \\
\text { individuals and the } \\
\text { organizational unit }\end{array}$ & \\
\hline \multirow{3}{*}{$\begin{array}{l}\text { Task as- } \\
\text { signment }\end{array}$} & \multirow{3}{*}{$\begin{array}{l}\text { Leader behavior } \\
\text { that aimed at clari- } \\
\text { fying work roles, } \\
\text { and responsibilities } \\
\text { that fits with the } \\
\text { passion and abili- } \\
\text { ties of their em- } \\
\text { ployee }\end{array}$} & $\begin{array}{l}\text { Provide } \\
\text { clear job description }\end{array}$ & \multirow{3}{*}{$\begin{array}{l}\text { Jeroen } \\
\text { P.J. de } \\
\text { Jong } \\
(2007)\end{array}$} \\
\hline & & 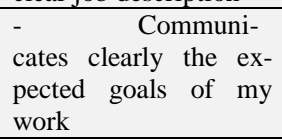 & \\
\hline & & $\begin{array}{l}\text { - Put me in } \\
\text { the position that fits } \\
\text { with my passion and } \\
\text { abilities }\end{array}$ & \\
\hline \multirow{5}{*}{$\begin{array}{l}\text { Innovative } \\
\text { work be- } \\
\text { havior }\end{array}$} & \multirow{5}{*}{$\begin{array}{l}\text { Employee behavior } \\
\text { that stimulate } \\
\text { individual innova- } \\
\text { tive and might } \\
\text { bring benefit for } \\
\text { them and the or- } \\
\text { ganization as well }\end{array}$} & $\begin{array}{l}- \\
\text { tion to issues that are } \\
\text { no part of his daily } \\
\text { work? }\end{array}$ & \multirow{5}{*}{$\begin{array}{l}\text { Jeroen } \\
\text { P.J. de } \\
\text { Jong } \\
(2007) \quad ; \\
\text { Nadin } \\
\text { Dorner } \\
(2012)\end{array}$} \\
\hline & & $\begin{array}{l}\text { - Wonder } \\
\text { how things can be } \\
\text { improved? }\end{array}$ & \\
\hline & & $\begin{array}{l}\text { - Search out } \\
\text { new working methods, } \\
\text { techniques or instru- } \\
\text { ments? }\end{array}$ & \\
\hline & & $\begin{array}{l}\text { - Generate } \\
\text { original solutions for } \\
\text { problems? }\end{array}$ & \\
\hline & & $\begin{array}{l}\text { Find new } \\
\text { approaches to execute } \\
\text { tasks? }\end{array}$ & \\
\hline
\end{tabular}

\begin{tabular}{|c|c|c|c|}
\hline Variable & Description & Items & Source \\
\hline & & $\begin{array}{l}\text { - Make im- } \\
\text { portant organizational } \\
\text { members enthusiastic } \\
\text { for innovative idea }\end{array}$ & \\
\hline & & $\begin{array}{l}\text { Attempt to } \\
\text { convince people to } \\
\text { support an innovative } \\
\text { idea? }\end{array}$ & \\
\hline & & $\begin{array}{l}\text { - Systemati- } \\
\text { cally introduce innova- } \\
\text { tive ideas into work } \\
\text { practices? }\end{array}$ & \\
\hline & & $\begin{array}{l}\text { Contribute } \\
\text { to the implementation } \\
\text { of new ideas? }\end{array}$ & \\
\hline & & $\begin{array}{l}\text { - Put effort in } \\
\text { the development of } \\
\text { new things? }\end{array}$ & \\
\hline $\begin{array}{l}\text { Job Per- } \\
\text { formance }\end{array}$ & $\begin{array}{l}\text { Observed variable } \\
\text { that can appropri- } \\
\text { ately represent } \\
\text { employee perfor- } \\
\text { mance }\end{array}$ & $\begin{array}{l}\text { last per- } \\
\text { formance score ranges } \\
\text { (based on the last Key } \\
\text { Performance Indicator) }\end{array}$ & $\begin{array}{l}\text { Drs. J. } \\
\text { Tanzil \& } \\
\text { Associat- } \\
\text { ed (2016) }\end{array}$ \\
\hline
\end{tabular}

Data collection in this research is using primary data. Data were collected by distributing questionnaire to employees in PT. XYZ. Questionnaire consists of 9 variables. Each of the statement will be measured using six points likert scale as explained in Table 2. Then the data will be processed using SPSS 21, SmartPLS 3 and Microsoft Excel 2010. The data Analysis is using PLS method. PLS is a multivariate statistical technique that performs the comparison between multiple dependent variables and multiple independent variables. PLS is designed to solve multiple regressions though specific data problems occur, such as small number of sample, missing data and multicollinearity problem. Partial Least Squares (PLS) has many advantages over regression, including the ability in resulting independent latent variables directly based on cross-product involving dependent variable latent as predictive power, the ability to analyze small sample sizes or data with nonnormal distributions. PLS enables the researcher to use different data types (nominal, ordinal, interval, and ratio).

Table 2: Point Likert Scale Used

\begin{tabular}{|l|l|}
\hline Construct & Scale used \\
\hline Consulting & $1:$ strongly disagree $-6:$ strongly agree \\
\hline Delegating & $1:$ strongly disagree $-6:$ strongly agree \\
\hline Support for innovation & $1:$ strongly disagree $-6:$ strongly agree \\
\hline Recognizing & $1:$ strongly disagree - 6: strongly agree \\
\hline Providing resources & $1:$ strongly disagree - 6: strongly agree \\
\hline Monitoring & $1:$ strongly disagree - 6: strongly agree \\
\hline Task Assignment & $1:$ strongly disagree - 6: strongly agree \\
\hline Innovative work behavior & $1:$ never - 6: always \\
\hline Job performance & $1:$ extremely bad - $6:$ extremely good \\
\hline
\end{tabular}

\section{Findings}

In the validity and reliability, four items were removed since they had loading factor $<0.7$. SmartPLS3 was used to test the relationship between 7 innovation-stimulating leader behaviors (consulting, delegating, support for innovation, recognizing, providing resources, monitoring, task assignment) and employee's innovative leader behavior and the impact to job performance.

Table 3: Path Coefficient and P-Value

\begin{tabular}{|c|c|c|c|c|c|c|}
\hline Variables & $\begin{array}{c}\text { Origina } \\
\text { Sample } \\
\text { (O) }\end{array}$ & $\begin{array}{c}\text { Sample } \\
\text { Mean } \\
(\mathrm{M})\end{array}$ & $\begin{array}{l}\text { Stand- } \\
\text { ard } \\
\text { Devia- } \\
\text { tion } \\
\text { (STDE } \\
\text { V) }\end{array}$ & $\begin{array}{c}\text { T Statis- } \\
\text { tics } \\
(\mid \mathrm{O} / \mathrm{STDE} \\
\mathrm{V} \mid)\end{array}$ & $\begin{array}{c}\mathrm{P} \\
\text { Values }\end{array}$ & Remarks \\
\hline $\begin{array}{l}\text { CONS }-> \\
\text { IWB }\end{array}$ & $\begin{array}{c}0.18 \\
9\end{array}$ & $\begin{array}{c}0.18 \\
4\end{array}$ & $\begin{array}{c}0.06 \\
7\end{array}$ & 2.815 & $\begin{array}{l}0.0 \\
03\end{array}$ & $\begin{array}{c}\text { Has significant } \\
\text { effect }\end{array}$ \\
\hline
\end{tabular}




\begin{tabular}{|lc|c|c|c|c|c|c|} 
DEL & $-y$ & 0.03 & 0.03 & 0.07 & 0.508 & 0.3 & Has no signifi- \\
IWB & 5 & 7 & 0 & & 06 & cant effect \\
\hline $\begin{array}{l}\text { SUPP } \\
\text { IWB }\end{array}$ & $->$ & $\begin{array}{c}0.02 \\
2\end{array}$ & $\begin{array}{c}0.02 \\
1\end{array}$ & $\begin{array}{c}0.09 \\
5\end{array}$ & 0.237 & $\begin{array}{c}0.4 \\
06\end{array}$ & $\begin{array}{c}\text { Has no signifi- } \\
\text { cant effect }\end{array}$ \\
\hline $\begin{array}{l}\text { REC } \\
\text { IWB }\end{array}$ & $->$ & $\begin{array}{c}0.12 \\
6\end{array}$ & $\begin{array}{c}0.11 \\
7\end{array}$ & $\begin{array}{c}0.08 \\
5\end{array}$ & 1.475 & $\begin{array}{c}0.0 \\
71\end{array}$ & $\begin{array}{c}\text { Has no signifi- } \\
\text { cant effect }\end{array}$ \\
\hline $\begin{array}{l}\text { PROV } \\
\text { IWB }\end{array}$ & $->$ & $\begin{array}{c}0.18 \\
4\end{array}$ & $\begin{array}{c}0.18 \\
5\end{array}$ & $\begin{array}{c}0.07 \\
3\end{array}$ & 2.510 & $\begin{array}{c}0.0 \\
06\end{array}$ & $\begin{array}{c}\text { Has significant } \\
\text { effect }\end{array}$ \\
\hline $\begin{array}{l}\text { MON } \\
\text { IWB }\end{array}$ & $->$ & $\begin{array}{c}0.00 \\
6\end{array}$ & $\begin{array}{c}0.00 \\
6\end{array}$ & $\begin{array}{c}0.07 \\
8\end{array}$ & 0.078 & $\begin{array}{c}0.4 \\
69\end{array}$ & $\begin{array}{c}\text { Has no signifi- } \\
\text { cant effect }\end{array}$ \\
\hline $\begin{array}{l}\text { TASK } \\
\text { IWB }\end{array}$ & $->$ & $\begin{array}{c}0.24 \\
4\end{array}$ & $\begin{array}{c}0.24 \\
9\end{array}$ & $\begin{array}{c}0.07 \\
5\end{array}$ & 3.250 & $\begin{array}{c}0.0 \\
01\end{array}$ & $\begin{array}{c}\text { Has significant } \\
\text { effect }\end{array}$ \\
\hline IWB $>$ JP & $\begin{array}{c}0.14 \\
4\end{array}$ & $\begin{array}{c}0.14 \\
7\end{array}$ & $\begin{array}{c}0.05 \\
8\end{array}$ & 2.503 & $\begin{array}{c}0.0 \\
06\end{array}$ & $\begin{array}{c}\text { Has significant } \\
\text { effect }\end{array}$ \\
\hline
\end{tabular}

Consulting (CONS), Delegating (DEL), Support for innovation (SUPP), Recognizing (REC), Providing resources (PROV), Monitoring (MON), Task Assignment (TASK), Innovative work behavior (IWB), Job performance (JP)

Table 3 presented the path coefficient and significant level of two related variables. These tests are run with an alpha level of 0.05 $(5 \%)$. If p-value $<0.05$ and t-value $>\mathrm{t}$-table (1.96) then the null hypothesis (H0) is rejected and the alternate hypothesis (H1) is accepted. Otherwise, the null hypothesis (H0) is accepted (Stone and Ellis, 2006).

\section{Conclusions}

According to the survey result and discussion, we conclude that:

- The Leader roles that has impact on Innovative work behavior (IWB) are consulting, providing resources, and task assignment.

- The Leader roles that has no impact on Innovative work behavior (IWB) are delegating, support for innovation, recognizing, and monitoring.

- Innovative work behavior has significant impact on job performance. The result implies that innovative employee actually leads to increased job performance and may eventually contribute to organization performance.

\section{Recommendations}

- In order to stimulate Innovative work behavior (IWB), Leaders should empower employees by providing considerable independence to subordinates in doing their jobs, show their enthusiastic on employee idea and creativity, give credit to employees for their innovative ideas, and always keep on tracking the progress of the innovative process.

- Put the right people into the right position to determine the success or failure of the task. Employees that have passion and ability in their work will be motivated to get better results rather than employees that have lack of ability or even don't like their job.

- Leader could seek to facilitate innovation by providing necessary resource including time and money, because lack of resources can affect the success of innovation that finally affect to employee and organization performance.

- For further study, others variable might added for the future research such as passion at work, educational background. Expanding the scope of research will be useful to learn more about innovation and its impact in other sector.

\section{References}

[1] Akram M, Ali L, Mughal M. M. The impact of leadership behavior on employees ' innovation: a comparative study of public and private sector organizations. Elixir Human Resource Management. 2012;48:9520-9525.
[2] Dorner, N. Innovative Work Behavior: The Roles of Employee Expectations and Effects on Job Performance. 2012;4007,1-120.

[3] Salah Satu Tools Dalam Upaya Meningkatkan Kinerja Karyawan [Internet]. Drs. J. Tanzil \& Associated. 2017 [cited 24 April 2017]. Available from

http://www.jtanzilco.com/blog/detail/606/slug/key-performanceindicators-kpi-salah-satu-tools-dalam-upaya-meningkatkan-kinerjakaryawan

[4] Janssen O. Job Demands, Perceptions of Effort-Reward Fariness and Innovative Work Behaviour. Journal of Occupational and Organizational Psychology. 2000;73(3):287-302.

[5] Jong J. P. J. D. Individual Innovation : The Connection Between Leadership and Employees' Innovative Work Behavior. Published PhD Thesis; Universiteit van Amsterdam, Netherlands; 2007.

[6] Jong J. P. J. D, Hartog D. N. D. Innovative Work Behavior: Measurement and Validation. Scientific Analysis of Entrepreneurship and SMEs. 2008;November:1-27

[7] Jong J. De, Hartog D. D. Leadership as a determinant of innovative behaviour: A conceptual framework. 2003.

[8] Jong J. P. J. D, Hartog D. N. D. How leaders influence employees' innovative behaviour. European Journal of Innovation Management 2007;10(1):41-64

[9] Oukes T. Innovative work behavior "A case study at a tire manufacturer [Internet]. September 2010 [cited 15 August 2017]. Available from

http://essay.utwente.nl/62728/1/Bacheloropdracht_T._Oukes_Septe mber_2011(publieke_versie).pdf

[10] Monecke A, Leisch F. SEM PLS : Structural Equation Modeling Using Partial Least Squares. Journal of Statistical Software. 2012;48(3):1-32.

[11] Patterson F, Kerrin M, Gatto-Roissard G. Characteristics and Behaviors of Innovative People In Organizations. Literature Review prepared for the NESTA Policy \& Research Unit. 2009: London: NESTA:1-63

[12] Porter M. E. The Competitive Advantage of Nations. Harvard Business Review. 1990;68:73-93.

[13] Pugno M, Depedri S. Job Performance And Job Satisfaction: An Integrated Survey. Economia Politica. 2010;27(1):175-210.

[14] Ringle C. M, Wende S, Becker J. M. "SmartPLS 3." Boenningstedt: SmartPLS GmbH. 2015

[15] Sholihin, Mahfud, Ratmono D. Analisis SEM-PLS dengan WrapPLS 3.0 Untuk Hubungan Nonlinear dalam Penelitian Sosial dan Bisnis. Yogyakarta, Penerbit ANDI; 2013.

[16] Tolbize A. Generational differences in the workplace [Internet] 2008 [cited 17 August 2017]. Available from: http://rtc.umn.edu/docs/2_18_Gen_diff_workplace.pdf. 